\title{
Effects of the 1994 Retsof Salt Mine Collapse in the Genesee Valley, New York
}

An apparent earthquake of magnitude 3.6 (Richter scale) centered near Cuylerville, N.Y., woke residents on March 12, 1994, at 5:43 a.m. and was detected by seismographs 300 miles away. The U.S. Geological Survey National Earthquake Information Center confirmed that a seismic event had occurred near Cuylerville. The Livingston County Sheriff's Department asked the Retsof Mine whether the earthquake could have resulted from mining activity. Mine personnel reported that they had not heard anything, nor felt any unusual ground motion, nor had they detonated any explosives that weekend. Retsof officials

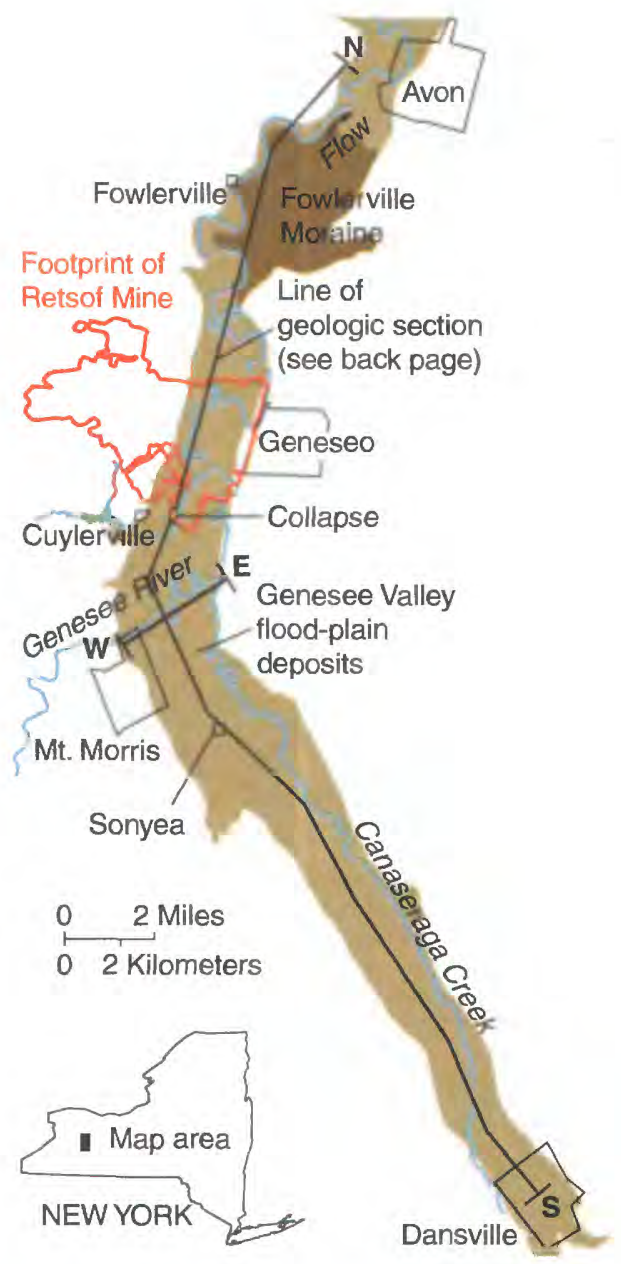

examined the mine and discovered that a 500 by 500 -foot section of shale ceiling rock had collapsed some 1,200 feet below land surface, in the southern part of the mine. Methane and hydrogen sulfide gases were escaping, and ground water was flowing from the collapsed ceiling into the room. The mine, which had been in operation since 1885 , had always been dry previously. This initial collapse was followed by another collapse and complete flooding of the mine, large ground-water level declines, and land-surface subsidence that affected many structures, roads, and utilities in this part of the Genesee Valley.

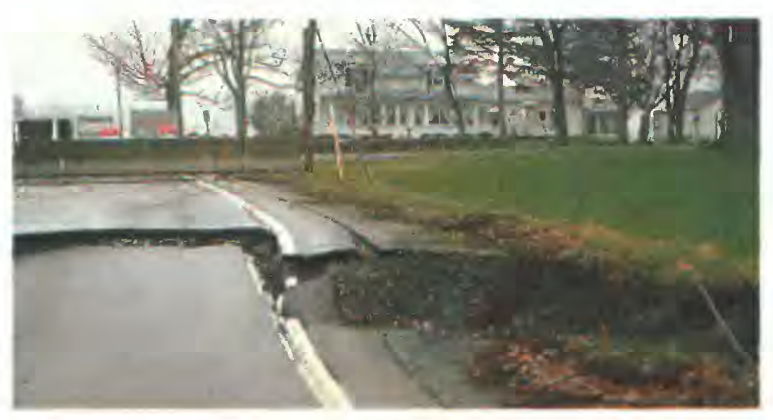

A roadbed fractured above the mine collapse area.

\section{History of the Mine}

The Retsof Mine was founded in 1885 as a vertical shaft was excavated to a layer of rock salt about 900 feet below land surface. During the next 110 years, this mine became the largest salt-producing mine in North America and the second largest in the world. Before the collapse in March 1994, the mine encompassed an underground area of more than 6,000 acres - nearly 10 square miles.

During the 17 months following the initial collapse, mining operations were shifted to the northern part of the mine in an attempt to salvage mineable salt before the entire mine became flooded. Mining operations ceased on September 2, 1995, and the mine was completely flooded by December of that year, 21 months after the initial collapse. 


\section{Hydrogeology of the Genesee Valley}

The Genesee Valley study area includes the Canaseraga Creek Valley from Dansville north to Mt. Morris, and the Genesee River Valley from Mt. Morris north to Avon. The Genesee Valley was formed by preglacial stream and glacial erosion of sedimentary bedrock that dips southward at about 42 feet per mile. The bedrock floor of the Genesee Valley consists of Hamilton Group Shales from Dansville north to near Sonyea; from there north to Fowlerville, it consists of Onondaga Limestone (see cross sections on back page). As much as 750 feet of unconsolidated sediments were deposited in the valley by glacial processes and another 50 feet of gravel, sand, and silt have been deposited on top of the glacial sediments by valley-floor and tributary streams since the glaciers receded about 12,000 years ago.
The principal aquifer system in the Genesee Valley is confined below the lacustrine (lake) deposits. A 10-foot-thick sand and gravel aquifer lies just below the lacustrine deposits, and a 10- to 40-footthick basal sand and gravel aquifer directly overlies the Hamilton Group shales in the southern part of the valley and the Onondaga Limestone in the central and northern parts. The hydraulic connection between the basal aquifer and the underlying bedrock units throughout the valley is poorly documented but is probably greatest in the northern half of the valley. The basal sand and gravel aquifer and water-bearing fractures in the Onondaga and Bertie Limestone bedrock are the major sources of ground water that flooded the Retsof Mine.
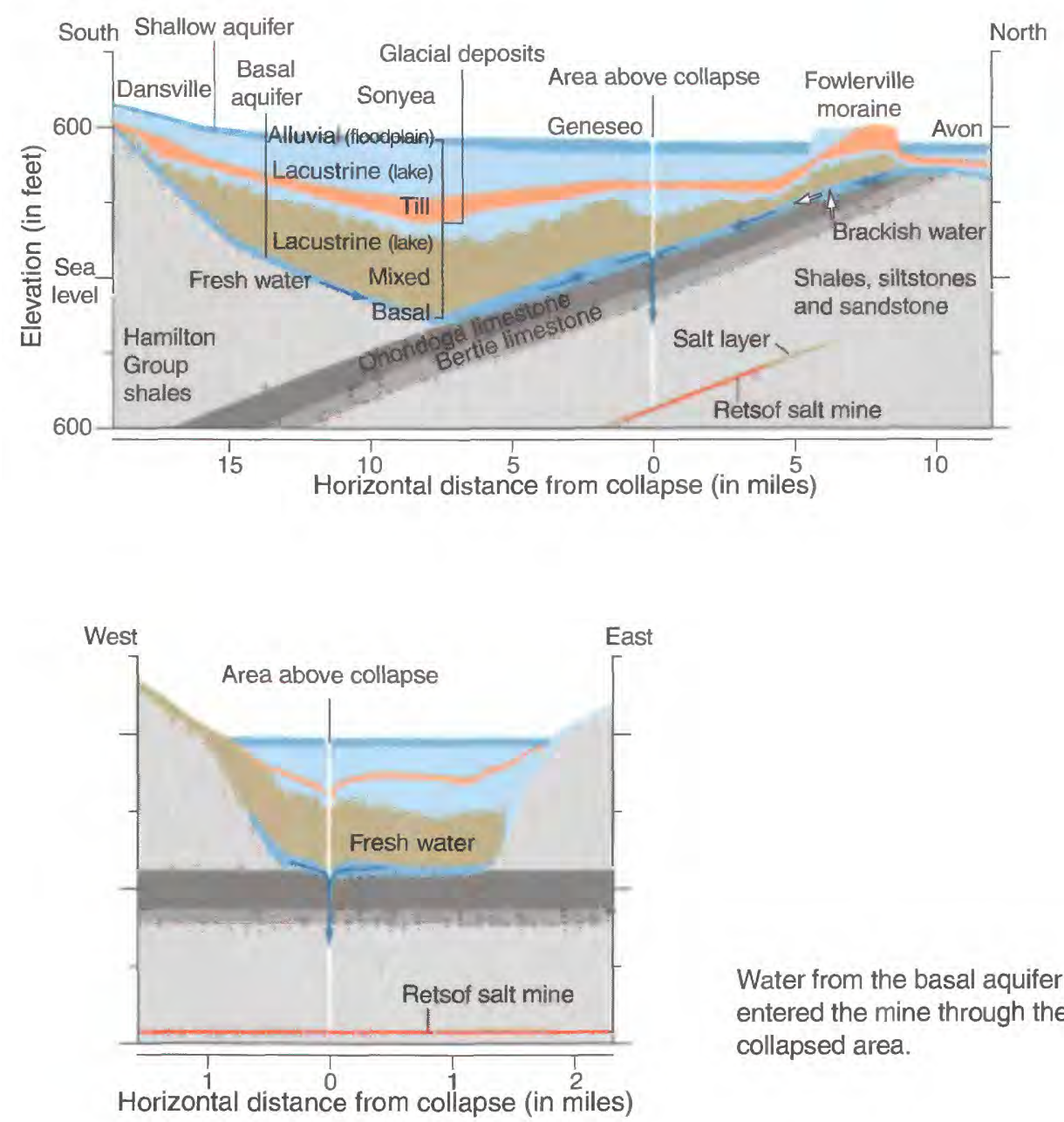

Water from the basal aquifer entered the mine through the collapsed area. 


\section{Hydrogeologic Effects of the Collapse}

The hydrogeologic effects of the mine collapse and the subsequent dewatering of overlying aquifers in the valley include, but are not limited to: (1) the loss of potable ground-water supplies through lowered water

- Ground-water level declines-After the mine collapse, water levels declined in several domestic wells along the edges of the Genesee Valley, and in wells that tapped the deeper aquifers. Shallow wells that tapped the unconfined alluvial aquifer were unaffected. The rate of water-level decline varied locally; for example, water levels declined 20 feet or more along Wheelock Road (about 1 mile south of Cuylerville) within 5 days of the

- Subsidence-Land subsidence caused by the collapse has resulted in the formation of two large (about 200 feet wide and 50 feet deep) sinkholes and the collapse of the State Route 20A bridge near Cuylerville. Several homes and barns, as well as agricultural lands and public utilities, were damaged by subsidence. In addition to the formation of 2 large sinkholes above the mine's southern end as a direct consequence of the March and April 1994 collapses, subsidence from three other causes has occurred in the valley: 1. Subsidence due to the slow but steady closure of the mine opening. This process generally occurs above any mined-out area, and mining engineers expect the land surface above the Retsof Mine to subside 8 to 9 feet over the next century or two. Differential (nonuniform) subsidence is expected along the margins of the mine, where stresses from adjacent subsidence may create enough tension to rupture the subsurface or surface. Horizontal movement and tilting of the land surface in the direction of the mine also can be expected in these areas. These areas may continue to be prone to structural damage over time.

2. Subsidence due to the dissolution of remaining salt. Engineering reports indicate that the magnitude of subsidence in the area of levels in wells, (2) short- and long-term land subsidence, and (3) impaired air quality as a result of the release of methane and hydrogen sulfide gases.

collapse, a decline of more than 100 feet was reported in one well in Mt. Morris during the next 2 months, and declines of 50 feet or more were reported in the Fowlerville area during the next 6 months. The largest water-level decline-greater than 400 feet-was reported near the mine-collapse area. The loss of water from the basal aquifer to the mine affected water levels within 10 miles north and south of the collapse area.

rapid freshwater inflow to the mine was greater than expected, and that the rate of subsidence was much greater than would be seen in a dry-mine situation. This type of subsidence, although rapid, progressed only in the area of freshwater inflow. Once the mine was filled with saturated saltwater, no new freshwater entered, and all subsidence of this type quickly decreased.

3. Subsidence due to the rapid lowering of ground-water levels in the principal aquifer, followed by a slow recovery. This type of subsidence is due to the compaction of finegrained layers generally within the confined aquifer below the lacustrine unit as ground water is drained, causing the removal of buoyant support between the individual silt and clay particles. Although this process caused a much smaller degree of land subsidence than the previously mentioned processes, the large declines in ground-water levels after the collapse were enough to cause some measurable elastic and inelastic compaction (consolidation) of the sediments, and this compaction resulted in small-scale land subsidence within an area larger than the underlying mine. This subsidence was greatest in areas where the fine-grained sediments are thickest.
- Release of natural gas from the aquiferSoon after the mine began to flood, the decline of water levels in the basal aquifer allowed natural gases (hydrogen sulfide and methane) to escape from the depressurized ground water, just as carbon dioxide gas comes out of solution, forming gas bubbles, when a bottle of carbonated soda is first opened. These gases escaped from test wells near the collapse, from some domestic wells along the eastern valley wall, and at land surface from fractures in the bedrock near the northwestern part of the mine. The gases were flared-off (burned) at several wells to reduce the odor and protect the health and safety of nearby residents. 


\section{USGS Efforts}

The collapse of the Retsof mine has caused major changes in the ground-water-flow system of the Genesee Valley. During the first few weeks of the mine collapse, the USGS provided hydrogeologic expertise to State and local officials as they assessed the immediate consequences. The USGS also assisted in developing a ground-water level monitoring network, collected surface- and boreholegeophysical data to characterize the hydrogeologic framework of the valley, and recently developed a numerical model of groundwater-flow in the aquifer system to simulate drainage of ground water into the mine and the recovery of water levels in the aquifer. The model is based on data supplied by Livingston County, State agencies, consultants, and the local citizens' Technical Assistance Group, as well as that collected by the USGS. The model is being used to delineate areas affected by water-level declines and to estimate the time required for the ground-water system to return to pre-collapse conditions. Model results will also be used to identify the factors that control the rate of drainage and recovery of the aquifer system, and the areas where additional hydrogeologic data are needed to improve the accuracy of the model.

\section{by William M. Kappel, Todd S. Miller, and Richard M. Yager}

\section{Sources of Technical Information}

Alpha Geoscience, 1996, Geologic and hydrogeologic investigation of the Genesee River Valley: Albany, N.Y., Alpha Geoscience, prepared for Akzo Nobel Salt Inc., Clarks Summit, Pa., 31 p.

Boyd, J. T., 1995, Impact analysis - Retsof Mine - Akzo Nobel Salt Inc., Livingston County, New York: Pittsburgh, Pa. John T. Boyd Co., Report No. 2455, 45p.

Dunn Corporation, 1992, Hydrogeologic report for the Akzo ash processing plant: Albany, N.Y., Dunn Corporation, prepared for Akzo Salt, Inc., Clarks Summit, Pa., 35 p.

Muller, E.H., Braun, D.D., Young, R.A., Wilson, M.P., 1988, Morphogenesis of the Genesee Valley: Northeastern Geology, v. 10, no. 2, p. 112-133.

Muller, E.H., Young, R.A., Rhodes,D.D., Willette, P., Wilson, M., and Fakundiny, R.H., 1981, Surficial geology of the Genesee Valley: New York State Geological Survey, Open-File Report 2044, 174 p.
Mullins, H.T., Wellner, R.W., Petruccione, J.L., Hinchey, E.J., and Wanzer, S., 1991, Subsurface geology of the Finger Lakes region, in New York State Geological Association 1991 guidebook - 63rd Annual Meeting, Oneonta, N.Y.: p. 1-54.

Shannon and Wilson Inc., 1995, Task 1 Report - Retsof Mine collapse - Technical Assistance Grant Committee, Retsof, New York, Report No. W-6983-01: Seattle, Wash., Shannon and Wilson, Inc., 42 p.

Van Sambeek, L. L., 1996, Dissolutioninduced mine subsidence at the Retsof Salt Mine, in Solution Mining Research Institute meeting papers: Cleveland, Ohio, October 20-23, 1996, p. 289-309.

Williams, J.H., 1996, Application of borehole geo-physics at the Retsof salt mine collapse site, western New York, in Bell, R.S., and Cramer, M.H., (eds.), 1996, Symposium on the Application of Geophysics to Engineering and Environmental Problems: Proceedings, April 28 - May 2, 1996, Keystone, Colorado, p. 813-821.

\section{For More Information contact: \\ Subdistrict Chief \\ U.S. Geological Survey \\ 903 Hanshaw Road \\ Ithaca, N.Y. 14850}

This fact sheet can be found on the WorldWide Web at: http//:ny.usgs.gov 